\title{
The Development of Democratic Consolidation in Turkey Since 2000s
}

\author{
M. Y1ldırım
}

\begin{abstract}
Turkey had its first experience of democracy in the 1950 elections. Later on, however, the country failed to achieve democratic consolidation because of 3 military coups, allowing the elements of military guardianship to cast a shadow on the political regime. With democracy efforts predominantly seen under stable, single party governments, Turkey has regained a positive momentum in terms of democracy, especially following the $\mathbf{2 0 0 2}$ elections. This study will outline the elements of military guardianship, and set light to the structural reforms aimed at eliminating it after 2002.
\end{abstract}

Index Terms-Democracy, guardianship, tutelage, military, coup.

\section{INTRODUCTION}

Having entered to the second period of republican era with the multi party elections in 1950, Turkey met with the tutelage regime centered by a military bureaucracy following the military coup on May 27, 1960. The "guardianship" concept was based on the idea that public, which lacks the modern and democratic values that are the essential elements of the Republic, cannot rule itself; therefore, a statist group of elite comprised of military and civil bureaucrats should undertake the task of governing. This guardianship maximized its level of institutionalization after the May 27 coup. This order enabled the military, which sees itself as the founder of the Republic and a bearer and protector of its ideals, to have an autonomous and privileged position within the system. Thus the military gained power to interfere with the social and political life, and reshape it in accordance with its own way of thought whenever it deems necessary.

Standing as the biggest obstacle against the rooting and strengthening of democratic traditions and institutions in the country, this military guardianship caused Turkey to fail in its struggle to become a real democracy. Just like 1961 Constitution, the 1982 Constitution, which took effect after the 1980 military coup d'état, also supported conservation of this authoritarian, statist, and pro-guardianship spirit within the political structure. The problems in the projected concept of democracy also led to serious restriction in the elbowroom of elected governments. For this reason, in Turkish political life, governments have been frequently become subject to epithets such as "incapable rulers". The reason for this was the difficulties in the elimination of pro- guardianship structure of the Constitution, which was restricting values such as democracy, state of law, and human rights. Started

Manuscript received December 13, 2013; revised February 11, 2014.

M. Yoldırım is with the Pamukkale University Turkey (e-mail: yildirimmutlu@hotmail.com). with the 1961 Constitution and reached to its climax through institutionalization by the 1982 Constitution, the armed forces' privilege was secured in three ways: privileges and powers acquired through the coups, the military jurisdiction, and the continuation of status quo through manipulation of fear.

\section{THE PRIVILEGES AND POWERS ACQUIRED THROUGH THE COUPS}

Referred to as "exit-guarantees" in literature, these privileges [1] are certain conserved areas and powers secured by the army through the 1960 coup with the aim of occupying a strong position in the decision making processes under constitutional guarantee. Within this context the 1961 Constitution (Article 110) entitled the members of the National Unity Committee as "natural senators" of the Republican Senate, and it positioned the Chief of General Staff (who was previously reporting to the Ministry of National Defense as per 1924 Constitution) under the Prime Minister. The National Security Council (N.S.C.) was initially designed by the 1961 Constitution (Article 111), which granted exemption to the members of National Unity Committee and its executors (Provisional Article 4), and secured a judicial immunity for the juristic dispositions accepted in the same period (Provisional Article 4) [2].

With the memorandum they gave on 12 March 1971, the military involved in politics once again and the constitutional amendments in 1971 and 1973 included paraphrases (Article 111) aimed at strengthening N.S.C. decisions ("shall notify" replaced with "shall suggest"), and it took the Turkish Armed Forces' (T.A.F.) expenditures out of the Court of Accounts' control (Article 127). In an effort to eliminate the unconstitutionality of Military Commission, the "natural judge" principle were turned into "legal judge" (Article 32), and the judicial power of the Military Commission were strengthened (Provisional Article 21). Transition to martial law was made easier through broadening of the reasons for proclamation of martial law (Article 124), and the military authority was granted substantial power within the jurisdiction through establishment of State Security Courts (S.S.C.) (Article 136). The civil jurisdiction was narrowed down through establishment of the Supreme Military Council, and the armed forces were provided with additional privileges through fortification of military influence on the jurisdiction [2].

Preserving the privileges given to the military through the 1971 and 1973 amendments, the 1982 Constitution hasreinforced the military power even further through the below mentioned authorities and privileges. In this context, 
the constitutional referendum and the presidential elections were combined (Provisional Article 1), in order to facilitate election of Kenan Evren, who has led of September 12 coups, as the President of the Republic. The National Security Council was transformed into Presidential Council (Provisional Article 2), and Turkish Armed Forces was taken out of the State Supervisory Council's audit mandate (Article 108). The President was granted a consolidated veto power and thus President Evren was given the authority to control the constitutional amendment on behalf of the military. The number of military members of the National Security Council was held higher than that of civil members and the council's judicial districts were broadened (Article 118), and decisions of the Supreme Military Council were excluded from jurisdiction (Article 125). The General Staff was entitled to assign members to the Board of Higher Education (Article 131), and the executives of the National Security Council period were granted a judicial immunity (Provisional Article 15, paragraphs 1 and 2). The juristic dispositions accepted in the National Security Council era were granted with judicial immunity (Provisional Article 15, paragraph 3) [3].

In brief, with every military intervention Turkish democracy was deeply wounded, and the army's privileges within the system grew even bigger, becoming increasingly more established. Thus the armed forces' possession of remarkably strong authorities that can be used during civil government process, and its subjection of elected civil administrators to the military's preferences through those authorities have become integral parts of Turkish political scene [4].

\section{THE MILITARY JURISDICTION}

Another step taken in the jurisdiction with the aim of strengthening the army after the May 27 coup d'état was restriction of judicial control on the military through new arrangements. Military jurisdiction and military higher jurisdiction organs were included into the Constitution; military jurisdiction was drawn as a constitutional institution, and it turned into an autonomous institution independent from judicial justice. Ümit Cizre defines this kind of military jurisdiction as "a government partner that locks its very own existence onto a perception of threat and security sanctifying and safeguarding the State, i.e. onto existence of 'others', and that identifies those 'others' by itself." [5] According to her, army acts as a "guardian" within the political system and it acquires certain privileges to itself through this role. In order to preserve the said privileges and its hegemony over the political system, it has to be effective in the political area. And in order for this interference to be effective and gain an institutional continuity, it should be held out of judicial control. This unique military justice system, the foundations of which were laid broadly by the 1961 Constitution, helped the armed forces use this area arbitrarily within the system. In fact, using this facility to the furthest extent, the military interfered with social life directly on May 27, March 12, and September 12, and indirectly on February 28 and as a result it secured continuity of its dominant position.

\section{Sustaining The System Through MANiPUlation OF}

FEAR

Continuity of a guardianship regime depends on the people's approval and consent to such regime. Therefore, the actors who are executors of the guardianship regime utilize certain mechanisms to justify their position in the public opinion. The most important one among these mechanisms is fear. The fear is pumped into society through fabrication of certain internal and external threats in an effort to legitimate the guardianship regime's role as the country's protector against such enemies and threats. These mechanisms for "manufacturing consent" are in fact mechanisms for manipulation of fear, from which the national security state gets its strength. With priorities changing from time to time, several internal and external threats (such as P.K.K., the Kurdish problem, economic issues within Turkey, and intentions of European Union, Russia, and Neighboring countries over Turkey) [6] were injected into the public opinion, securing continuity of the guardianship regime.

This regime in Turkey has long been subject to serious criticism both within the country and at international level. Nevertheless, within this context, political governments did try to implement significant reforms with the aim of improving the standards of democracy in Turkey. While the coalition governments established before 2000s have also made certain efforts, the political instability and economic problems combined with the pro-guardianship and elitist bureaucratic structure that stands over governments averted the country from attaining world-class democratic norms. That said, Turkey's political era between 2002 and 2012 is especially important in terms of democratic development. The main reason for this is the era's pro-guardianship actors' clear and effective intentions to oppress the political power, which later led the political power to implement various reforms as a reaction. The other reasons that make this period important are the very strong parliamentary majority supporting the political government, and the very important reforms on democracy, state of law, and human rights.

This study aims to discuss the positive and negative aspects of the reforms made within this period. In Turkey, the public opinion's wishes for implementation of structural reforms in the judicial order fall short. For this reason the political will must realize initiatives aimed at those reforms. Nevertheless, in an environment where the bureaucratic pro-guardianship structure is believed to be protected strictly by its own actors, any step aimed at changing the status quo may encounter resistance. Therefore, realization of changes that may be designated as a wave of democratization requires strong and committed political governments. In order for such reforms to be implemented, also a stable period is needed. This explains why the strong democratization initiatives within 1982 Constitution era fall only to the stable periods under rule of single party governments.

In this context two periods deserve mention: First is the Motherland Party (ANAP) government between 1983 and 1991, and the second one is the Justice and Development Party (AK Party) government between 2002 and 2012. In the first period, democratization was surpassed by changes and transformations experienced in the economical area 
However, under Justice and Development Party government, which comprises the second period, it is obvious that the democratization steps taken have been at least as strong as those taken in the economical area. As shown below, while the democratization achievements within this period are very important steps forward, certain critical shortcomings also show that even this government has been insufficient in implementation.

\section{DEVElopMENT OF DEMOCRACY}

While the 1982 Constitution was accepted with a public support as big as $92 \%$, especially the problems it has caused in implementation have led to criticism of the Constitution. The amendments also prove these critics right. Turkey's application to full European Union membership on 14 April 1987 and the Copenhagen Criteria it was required to realize thereafter have also contributed to Turkey's democratization. These criteria, which incorporate three titles including the enhancement of human rights standards, a civil democracy freed from guardianship, and a free market economy, are in fact seen as indispensables of the democratization process in Turkey. The only criticism that may be made on this topic is Turkey's efforts to realize these movements with the influence of international dynamics, instead of using its own domestic dynamics. Nevertheless, thanks to the strong and stable single party government, 2000s also witnessed the weight of domestic dynamics within the democratization process, in addition to the external dynamics.

Since the 1961 Constitution, the concept of guardianship, which has been seen as a fundamental problem over politics, became clearer especially during the single party government periods. In the 1982 Constitution period, both Ozal governments and Erdogan governments felt the intensity of tutelage at different severity levels. Mostly dominated by the National Security Council, the concept of guardianship has been moved to a different dimension where jurisdiction became more effective.

This situation, which may be called as judicial guardianship, showed itself during this period perhaps most intensively since the 1961 Constitution. On one hand, in an activist stance the Constitutional Court annulled laws made by the Grand National Assembly of Turkey (G.N.A), which were in compliance with the Constitution and within its discretion, by performing legitimacy controls; confronted the political power's steps on various topics such as privatization, social security, democratization, and state of law; and even exaggerated its activism by questioning the grounds of constitutional amendments realized by this government, and cancelling them. On the other hand, the State Council annulled constitutional steps of governments by exceeding compliance audits, and thus tried to restrict the government's area of movement. When considered in terms of the state of law, while judicial control is necessary, with such controversial decisions taken by exceeding its jurisdiction, the Constitutional Court and the State Council have been subject to heavy criticism.

Under the AK Party government, two important constitutional amendments were made against this pro-guardianship, bureaucratic, elite resistance based on jurisdiction. The first one, which followed a decision [7] taken by the Constitutional Court within the eleventh Presidential election at G.N.A. in 2007, introduced popular vote for Presidential elections. With introduction of popular vote for electing the President, which has been an important actor in the pro-guardianship model as planned by the 1982 Constitution, negativities such as oppression, intimidation, illegality, crisis, etc., which have been experienced during the presidential election processes from time to time since 1961, would be eliminated. Similarly, the 2010 Constitutional amendments became subject of a popular debate. Thus, the fact that these two amendments, which were aimed at eliminating the pro-tutelage structure foreseen by the 1982 Constitution, have been accepted with popular vote actually shows that people also believe that these structural reforms now need to be realized.

These developments show that, in 2000s, not only external dynamics but also grassroots demands have also played a determinant role in the steps taken towards democratization.

In the ten years period, some of the implemented reforms related to democratization, human rights, and state of law, which will be discussed herein, have taken place in form of Constitutional amendments, while others were at legislative level. Some reforms were only focused on a particular topic while others -like those in the 2010 constitutional amendments- covered different topics.

\section{StePs TAKEN IN THE FiELD OF DEMOcRATIZATION}

One of the most important steps taken within the context of demilitarization and assimilation of the guardianship was annulment of the state of emergency in the eastern and southeastern Anatolia. The strong authorities held by administration and effective restrictions on human rights under the state of emergency have caused serious problems. Especially the restrictions on judicial review, which occur under the state of emergency administrations, show the extent of serious worries about human rights in that period. With addition of the armed forces' forcibleness in those days, it can be said that the state of emergency administrations have been one of the major obstacles against democratization. Emerged as result of the terrorist actions experienced during 1980s in certain provinces of Eastern and Southeastern regions of Turkey, the state of emergency had been gradually lifted in some provinces, and it was completely annulled in 30 November 2002. Likewise, the State Security Courts, which had been introduced to the judicial system with 1973 Constitutional amendments, have been subject to continuous criticism about democracy. As result of Turkey's conviction by the European Court of Human Rights (E.C.H.R), which had found Turkey guilty of violating the right of fair trial by assigning a military judge to the State Security Court, attendance of military judges to State Security Court proceedings have been annulled with the Constitutional amendment in 1999 [8]. After that, these courts were completely eliminated in 2004. Later on, the State Security Courts were replaced by specially authorized high criminal courts, which were established to handle organized crimes including but not limited to cases related to national security. Due to the troubles that had been encountered in that decade, 
the special high criminal courts have also been lifted with the Law No. 6352 dated 02.07.2012 and a new provision in the third judicial package that was adopted.

Another amendment was related to the General Secretariat of the National Security Council. Considered as one of the most important institutions of the pro-guardianship model in Turkey, the National Security Council was initially introduced in the 1961 Constitution, and it continuously gained strength against civil power since then. The seventh harmonization package also included amendments related to the General Secretariat of the National Security Council, and through several changes in the National Security Council, which was adopted with the 2001 Constitution amendment, the dominance of the armed forces started to be reduced (For the decision see Grounds No.: 2007/45, Decision No.: 2007/54; Date of Decision: 1.5.2007).

The amendment paved way for a civil Secretary General for the National Security Council. In fact, the new rules mean that the National Security Council General Secretary will be assigned with the proposal of the Prime Minister, and approval of the President [9]. With the amendment made in 2003, the strengthening of civil politics in the Council should be seen as the second important step.

Constriction of the military jurisdiction is yet another important step towards democratization. In fact, two positive steps in this context deserve mention. First of all, with the Law no. 4963, the applicability of Military Penal Code to non-military persons was constricted. Secondly, for their criminal acts including attempted coups or coup crimes, members of military would be directly adjudicated at general courts. Accordingly, upon the Constitutional Court's annulment of the new legal arrangement based on Article 145 of the Constitution, the subject was addressed at constitutional level with the 2010 Constitutional amendment.

The Security - Public Order - Cooperation (E.M.A.S.Y.A.) protocol established on 7 July 1997 with an agreement between Interior Ministry and General Staff had authorized the military to intervene social events at its own discretion. This practice, which caused intensive debates, was annulled with the new agreement signed between the Interior Ministry and the General Staff on 04.02.2010 (In fact, all the N.S.C. General Secretaries assigned after the amendment have been civil persons (Mehmet Yiğit Alpogan, Ambassador 01.10.2004-16.07.2007, Tahsin Burcuoğlu, Ambassador 01.11.2007-25.01.2010, Serdar Kilıç, Ambassador 05.02.2010 17.04.2012, Muammer Türker, Governor 25.04.2012).

Again in this context, steps were taken against placement of military men in certain state institutions. The major examples are the amendment dated 07.05.2004 in Article 131 of the Constitution, which terminated the General Staff's right to assign members to the Higher Education Council, and the amendment brought with the Law No. 5218, which changed the provision related to the election of a Higher Education Council member by the General Staff. Secondly, with the amendment in the Law No. 5218 related to Establishment and Broadcasting of Radio and Televisions, the provision that authorized the Secretary General of National Security Council to make nomination for the Radio and Television High Council was repealed. The same Law also terminated the N.S.C. General Secretary's membership to the Higher Council of Communication.

Another reform introduced with the 2010 Constitutional amendment was related to the judicial control of the decisions of Supreme Military Council. Previously, all the decisions of the Supreme Military Council were exempt from judicial review. With this amendment, any kind of promotion procedures and severance decisions (except for the retirements due to lack of staff) of the Supreme Military Council were opened to judicial remedy (1982 Constitution, Article 125) [10].

Another important step that deserves mention is the Provisional Article 15 of the 1982 Constitution, which was annulled with the 2010 Constitution amendment. The lifted provision was preventing adjudication of the National Security Council members who were involved in the September 12, 1980 military coup. For the National Security Council members who made the 27 May 1960 Military Coup, a similar provision was also present in the Provisional Article 4 of the 1961 Constitution. Annulment of the Provisional Article 15, 30 years after the 1980 Military Coup, should still be seen as a symbolic yet important step. Indeed, given the similar restrictions of control since 1960, the amendment in 2010 demonstrates a symbolic sensitivity against lack of a comparable step in any of the reforms carried out in other times. In fact, the trials against living members of 12 September's National Security Council, which started as result of this step, are meaningful.

\section{OTHER DEVELOPMENTS}

Another step taken includes reforms related to local administrations. The improvements that made positive contribution to the local administrative structure in Turkey include the Metropolitan Municipality Law No. 5216 dated 2004, the Provincial Special Administration law No. 5302 dated 2005 [11], the Law No. 5355 regarding Associations of Local Administration, and [12] the Municipality Law No. 5393 [13]. These laws brought important improvements by readdressing the local administrative units in accordance with contemporary requirements. The main characteristic of these laws in terms of democracy is their aim at breaking the central administrations' dominance on local administrations, and moving to a configuration that is more in line with the requirements of democracy.

As required by its signature on the European Convention on Human Rights, with the Law No. 4928 dated 15.07.2003, Turkey accepted the verdicts of conviction made by E.C.H.R. against the administrative jurisdiction as a reason for retrial. Thus, E.C.H.R.'s verdicts of conviction against Turkey were accepted as a reason for retrial based on the Administrative Jurisdiction Procedures Law, the Civil Procedure Law, and the Code of Criminal Procedure.

Similarly, right to information, which is an important right for establishment of a democratic administration, was entered into our legislation with the Right to Information Act No. 4982 dated 09.10.2003, and the 2010 Constitutional amendment introduced an Ombudsmanship Institution with the addition of title related to "the right to appeal to the ombudsman" to Article 74 of the Constitution. The right for 
individual appeal to the Constitutional Court, which has been accepted with the 2010 Constitutional amendment, was designed as a preventive measure against Turkey's conviction by the E.C.H.R. The 2010 Constitutional amendment brought the provision that "everyone may apply to the Constitutional Court with the claim that any of his fundamental rights and freedoms assured by the Constitution within the scope of European Convention on Human Rights are violated by a public power" (Article 148/3) [14] .

With the 2010 Constitutional amendments, steps for reducing the restrictions on judicial control were taken, paving the path for judicial remedy against any kind of promotion procedures and severance decisions (except for the retirements due to lack of staff) of the Supreme Military Council. On the other hand, public servants were given the right to appeal for remedy against warnings and reprimands. Judicial remedies against Supreme Board of Judges and Prosecutors' (S.B.J.P.) dismissal decisions were also made available. Despite these positive steps, the fact that certain Supreme Military Council (S.M.C.) and S.B.J.P. decisions and President's individual actions are still exempt from remedy are seen as important obstacles for the state of law. With the 2010 Constitutional amendment, the S.B.J.P.'s structure was changed substantially: the number of Board members was increased from 7 to 22 , with three members from among judges and prosecutors working at administrative procedure trial courts, seven members from among judges and prosecutors working at courts of original jurisdiction, one member from Turkish Academy of Justice, and four members through president's nomination from among legist faculty members and attorneys. Thus, the Board attained a more mixed and pluralist structure, becoming nearer to a formation that is seen in high judiciary institutions in the European countries [15].

A similar practice was experienced in the formation of the Constitutional Court: the previous formation, which was comprised of eleven permanent members and four reserve members, was replaced with a formation that is comprised of seventeen permanent members, and the reserve membership status was annulled. With introduction of a term of office limited to 12 years, the practice that allowed the court members to remain in post until 65 years old was also terminated. The fact that G.N.A. is not allowed to nominate any of the members directly can be considered as the most important deficiency regarding the formation of the Constitutional Court. In Europe, in fact, it is impossible to find an example where the national parliament is not allowed to choose a member to this institution. Conversely, in certain countries like Federal Republic of Germany, Poland, and Hungary, all the members of the Constitutional Court are being elected by the parliaments [16].

The political will has taken aim at developments regarding language, too. In this context the legal barriers against broadcasts in different languages and dialects on private televisions and Turkish Radio Television (T.R.T.) were lifted with the Law No. 4928 dated 19.07.2003. Whereupon "the Regulation Regarding the Radio and Television Broadcasts to be made in Different Languages and Dialects Traditionally Used by Turkish Citizens in their Daily Lives" was drafted and executed, allowing radio and television broadcasts in different languages and dialects. On the other hand, the Law No. 5980 dated 08.04.2010 allowed political parties to carry out election campaigns and propaganda in different languages and dialects used by citizens, while some settlements started to use their local names or take back their original names.

As is known, Turkey had lifted capital punishment for normal periods in 2001. In 2004, the capital punishment was lifted completely including extraordinary situations, and it was totally removed from the legislation. Subsequently, the United Nations and the European Council protocols related to the lift of capital punishment were also approved.

The 2010 Constitutional amendment brought two important reforms in terms of the liberties of political parties. First of all, in political party closure cases, a deputy who has caused its party to be closed will not be dismissed from deputyship. Given that closure is an important sanction for a political party, this reform may also be seen as a positive step. Secondly, any Constitutional Court decision for closure of political parties or for their divestiture from state assistance will require two thirds majority of the attending members. Given that the previous quorum was three fifth, this increase to two thirds has created a more secure situation in terms of political parties' freedoms [17].

\section{CONCLUSION}

During the single party government of the last decade, the democratization steps taken by the Justice and Development Party have made serious contributions to solution of problems faced by Turkey. In combination with the contributions of developments in the economical field, the reforms related to democracy, human rights, and state of law have also increased Turkey's prestige. However, since Turkey still struggles with important problems in terms of democratization, these steps should be continued in a more determined manner.

Today, while there is no apparent problem related to military guardianship, the actual state should not be considered sufficient and permanent solutions should be introduced. For this reason, the essential constitutional and legal amendments must be made as soon as possible. Accordingly, the General Staff must be linked to the Ministry of National Defense, the National Security Council must be excluded from being a constitutional institution, and the separation of civil-military jurisdiction must be ended through termination of high courts in the field of military justice. The process for the new constitution must be completed successfully. In this process, attention ought to be paid to have all political parties participate to the making of the new constitution.

In fact, following the June 2011 general elections, despite all the difficulties in its formation and decision-making, the first Great National Assembly of Ottoman-Turkish political history that is comprised of merely the people's representatives based on merely people's demands, has started the process for making of a new constitution by forming a commission comprised of equal number of members from each party, without intervention of the actors of guardianship. This new development was indeed 
extremely important with its demonstration of the political level attained by Turkey. However, the requirement of unanimity for acceptance of articles have prevented the parties from reaching an accord, and caused the process to fail.

\section{REFERENCES}

[1] S. Valenzuela, "Democratic consolidation in post-transitional settings: Notion, process and Faciliting conditions, Mainwaring, S. O'Donnel,' The New South American Democracies in Comparative Perspective, Notre Dame: University of Notre Dame Press, 1992, pp. 62-66.

[2] TÜRk Anayasa Hukuku Sitesi. [Online]. Available: http://www.anayasa.gen.tr/1961anayasasi.htm

[3] S. Yazıc1, Türkiye'de Askeri Müdahalelerin Anayasal Etkileri, Yetkin Yayınlar1, Ankara, 1997, pp. 75-201.

[4] S. Yazıc1, Demokratikleșme Sürecinde Türkiye, İstanbul Bilgi Üniversitesi Yayınları, İstanbul, 2009, p. 80.

[5] Ü. Cizre, "Evrenselden yerele asker ve İktidar," Stratejik Boyut, no. 7, pp. $10-11,2010$.

[6] A. İnsel. (2010). Vesayet Rejiminin Sonu Ve Sonrası. [Online]. Available:

http://www.birikimdergisi.com/birikim/dergiyazi.aspx $?$ did=1\&dsid=3 $89 \&$ dyid $=5753 \&$ yazi

[7] Y. Ş. Hakyemez, "Anayasa Mahkemesinin Yargısal Aktivizmi ve İnsan Hakları Anlayıșı," Stratejik D, 2012, pp. 63-171.

[8] E. Özbudun, “Türk Anayasa Mahkemesi’nin Yargısal Aktivizmi ve Siyasal Elitlerin Tepkisi," AÜSBFD, vol. 62, no. 3, 2007.

[9] Y. M. Bülteni, "Çıraklar/Türkiye Davası," Yargı Mevzuatı Bülteni, no. 82, pp. 19-30, 1999.

[10] For the decision on the cancelled legal arrangement see Grounds. [Online]. Available: http://www.resmigazete.gov.tr/eskiler/2010/01/20100127-8.htm

[11] Hürriyet Newspaper, EMASYA Protokolü Kaldırıld, 2012.
[12] Türk Anayasa Hukuku Sitesi.

[Online].

Available: http://www.anayasa.gen.tr/1982ay.htm

[13] Mevzuatı Geliștirme Ve Yayın Genel Müdürlüğünce Yayımlanır. [Online].

Available: http://www.resmigazete.gov.tr/eskiler/2004/07/20040723.htm

[14] MEVZUAT.

[Online].

Available: http://www.mevzuat.gov.tr/Metin.Aspx?MevzuatKod=1.5.5302\&sour ceXmlSearch $=\&$ MevzuatIliski $=0$

[15] Mahallî Idare Birlikleri Kanunu. [Online]. Available: http://www.tbmm.gov.tr/kanunlar/k5355.html

[16] Belediye Kanunu. [Online]. Available: http://www.tbmm.gov.tr/kanunlar/k5393.html

[17] Sosyalbilgiler. [Online]. http://www.sosyalbilgiler.gen.tr/2010-anayasa-degisikligi-/

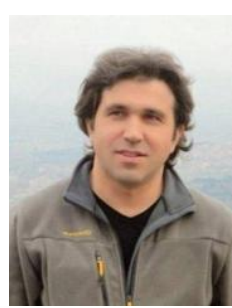

Mutlu Yıldırım was born in 1977 in Usak, Turkey. He completed his primary, secondary, and high school education in Usak, Y1ldırım later graduated from Bilkent University Department of Political Sciences and Public Administration in 2001. In 2010, he obtained post graduate degree in Pamukkale University Department of Political Sciences and Public Administration with his thesis titled "1966-1973 Presidential Elections within the context of Civil-Military Relations in Turkey". He is still continuing his doctorate at the Same University. Mutlu Yildırım continues his studies on Turkish Democracy, civil-military relations and voter behavior. Y1ldırım has two published articles: "Nepotism and merit in public administration" and "The impact of voter behavior of party candidate preferences, case of 2009 Usak local election". 